\title{
Factors associated with survival of reintroduced riparian brush rabbits in California
}

\author{
Laurissa P. Hamilton ${ }^{\mathrm{a}, \mathrm{b}, *}$, Patrick A. Kelly ${ }^{\mathrm{a}}$, Daniel F. Williams ${ }^{\mathrm{a}}$, Douglas A. Kelt ${ }^{\mathrm{b}}$, Heiko U. Wittmer ${ }^{\mathrm{b}}$ \\ ${ }^{a}$ Endangered Species Recovery Program, Department of Biological Science, California State University, Stanislaus, One University Circle, Turlock, CA 95382, USA \\ ${ }^{\mathrm{b}}$ Department of Wildlife, Fish, and Conservation Biology, University of California, One Shields Avenue, Davis, CA 95616, USA
}

\section{A R T I C L E I N F O}

\section{Article history:}

Received 25 March 2009

Received in revised form 5 January 2010

Accepted 11 January 2010

\section{Keywords:}

Survivorship

Reintroduction

Controlled propagation

Program MARK

Sylvilagus bachmani

Endangered species

\begin{abstract}
A B S T R A C T
The riparian brush rabbit (Sylvilagus bachmani riparius) is an endangered species found in dense, brushy habitat in the California's Central Valley. We implemented a reintroduction program to bolster populations at a Federal Wildlife Refuge and to assess factors influencing mortality and subsequent survival of released individuals. Between July 2002 and July 2005, we reintroduced 325 captive-bred individuals to unoccupied habitat within their historic range using a soft-release strategy and monitored their subsequent survival with radiotelemetry. Longer time in soft-release pens resulted in increased monthly survival. Rabbits were most susceptible to post-release mortality during the first 4 weeks following reintroduction and both body mass and length of time in the soft-release enclosure influenced this relationship. When we controlled for release mortality during this acclimation period, subsequent monthly survival probabilities were most strongly influenced by release year (year 1 vs. years 2 and 3 ) and by a catastrophic flooding event; length of time in the soft-release enclosure remained an important variable in longer-term survival. Cause of mortality was unknown for the majority of deaths (61.9\%), but predation (including presumptive predation) was the greatest known cause of death in translocated rabbits (26.4\%). Reintroduction programs should employ an adaptive management approach with ongoing monitoring of target animals and concurrent analysis to allow managers to adjust methods as conditions dictate.
\end{abstract}

(C) 2010 Elsevier Ltd. All rights reserved.

\section{Introduction}

Species reintroduction involves the establishment of populations within their historic geographic range where they have been extirpated. Reintroduction is an increasingly common practice in conservation management (Griffith et al., 1989; Kleiman, 1989; Sarrazin and Barbault, 1996; Snyder et al., 1996; Seddon et al., 2007), and may involve translocation (or relocation) of individuals from one portion of their range to another or release of captivebred animals into formerly occupied parts of their range (see Fischer and Lindenmayer (2000) and Armstrong and Seddon (2008) for further discussion of associated terminology). Reintroductions, however, commonly have low success rates. For example, Fischer and Lindenmayer (2000) reported that only $26 \%$ of reintroductions were classified as successful; fully $27 \%$ failed, and $47 \%$ were unknown at the time of publication.

Because of the difficulties associated with performing effective reintroductions, understanding factors that influence success is

\footnotetext{
* Corresponding author. Address: Department of Wildlife, Fish, and Conservation Biology, 1088 Academic Surge, University of California, One Shields Avenue, Davis, CA 95616, USA. Tel.: +1 209613 7787; fax: +1 5307524154

E-mail addresses: lphamilton@ucdavis.edu (L.P. Hamilton), pkelly@csustan.edu (P.A. Kelly), dfwilliams@bendcable.com (D.F. Williams), dakelt@ucdavis.edu (D.A Kelt), huwittmer@ucdavis.edu (H.U. Wittmer).
}

critical. The likelihood of success in animal relocations appears to increase when: (1) a wild source population is used, (2) large numbers of animals $(n>100)$ are released (either in one large group or several smaller releases), and (3) the cause of decline was addressed and removed prior to reintroduction efforts (Kleiman, 1989; Fischer and Lindenmayer, 2000). Successful translocations also correlate with habitat quality, proximity to the core of the range rather than the periphery, and the duration of the translocation effort (Griffith et al., 1989; Wolf et al., 1996). However, understanding species-specific characteristics and their impact on relocation success is required to design better reintroduction methods and to identify the best candidates for translocation (Wolf et al., 1996).

The success of reintroductions can be facilitated through various mechanisms. For example, soft-releases allow for acclimation to a new location prior to release and familiarity with places to shelter and escape predation (Davis, 1983; Moore and Smith, 1991; Bright and Morris, 1994; Carbyn et al., 1994; Biggins et al., 1999). Release strategies allowing translocatees to maintain social relationships with individuals in the release cohort have also been shown beneficial for species that rely on social interactions for predator avoidance (e.g., prairie dogs (Cynomys ludovicianus) Shier, 2006). Pre-release training can assist translocatees in the development of anti-predator behavior prior to reintroductions (McLean, 1997; Alberts, 2007). Post-release survival improved for 
captive-born houbara bustards (Chlamydotis undulata) that had been exposed to live rather than simulated predators (van Heezik et al., 1999). Finally, pre-conditioning animals to release site settings, such as by raising them in environments that are similar to those in which they will be reintroduced, also can provide survival benefits (Fiechter et al., 1988).

Riparian brush rabbits (Sylvilagus bachmani riparius) occupy areas of thick, brushy cover along rivers and tributaries in California's Central Valley (USFWS, 1998). Brush rabbits are dependent on brushy understory cover for protection and travel via tunnels under dense vegetation to avoid predators (Orr, 1940; Chapman, 1971). Thus, availability of riparian habitat is crucial for the survival of this species. By the mid-1980's, reflecting primarily habitat loss and destruction, the riparian forest within the former range of the riparian brush rabbit had been reduced to a few small and widely scattered fragments, totaling about 2100 ha (Warner, 1984; Larsen, 1993). As a result, this species was listed as endangered by the state of California in 1994 (CDFG, 2008) and by the US Fish and Wildlife Service in 2000 (USFWS, 2000). Currently, only two extant populations of riparian brush rabbits are known; both are small and at risk of imminent extinction from demographic and/or environmental stochasticity (including or resulting from flooding, wildfire, habitat conversion, disease, predation), and possibly from competition with desert cottontails (Sylvilagus audubonii; Williams and Basey, 1986; Williams, 1988; USFWS, 1998).

Due to the urgent threats faced by the wild population, a reintroduction project was initiated in November 2001 (Williams et al., 2002). As a source of animals for reintroduction a parallel controlled propagation program was initiated in large pens within riparian brush rabbit habitat (Williams et al., 2008). The controlled propagation program used individuals taken annually from the wild population to produce progeny for reintroduction. This reintroduction therefore meets two of the three criteria recommended by Fischer and Lindenmayer (2000). Consequently, the riparian brush rabbit reintroduction project provides a valuable opportunity to explore questions pertaining to release strategies and factors likely to increase survival probabilities of reintroduced individuals.

We recently reported an overview of the controlled propagation program, including data on reproductive success among confined rabbits, and survival of translocated rabbits between 2002 and summer 2004 (Williams et al., 2008). Here we build on this report by explicitly analyzing factors associated with the survival of reintroduced riparian brush rabbits. Specifically, we report on survival of rabbits during the first 12 weeks post-release as functions of release cohort size, length of time in the soft-release enclosure, and reproductive status, allowing us to determine an "acclimation period" after which survival is markedly elevated. For animals surviving the acclimation period, we evaluated temporal variation in survival and the effects of environmental stochasticity, including wildfire and flooding, allowing clear differentiation between mortalities associated with release vs. those attributable to environmental conditions. We believe that reintroductions should be treated in an adaptive management framework, and towards this end we apply this information to provide recommendations for improving the success and efficiency of this program.

\section{Materials and methods}

\subsection{Study area}

Our reintroduction site is the San Joaquin River National Wildlife Refuge (Refuge hereafter), located on the San Joaquin River approximately $18 \mathrm{~km}$ west of Modesto in Stanislaus County, California (37.615N, 121.213W; Fig. 1). The Refuge comprises

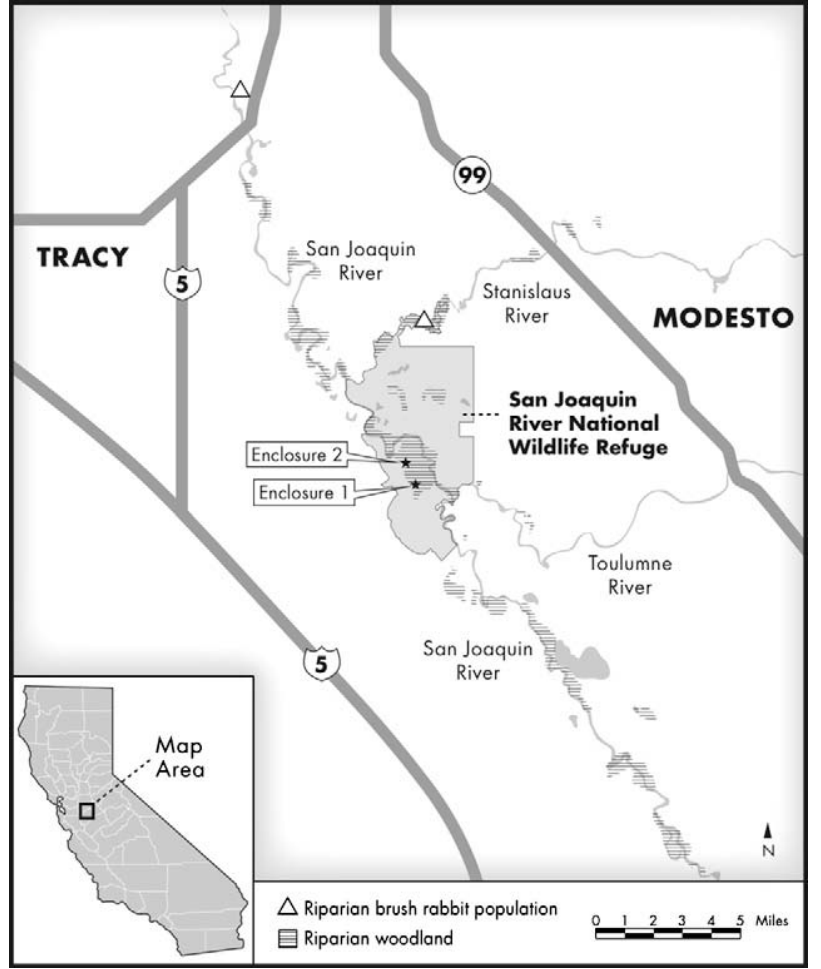

Fig. 1. The San Joaquin River National Wildlife Refuge, California, USA. Enclosures \#1 and \#2 refer to soft-release enclosures.

2688 ha and was established in 1987 for the conservation of endangered species and migratory birds, and to provide foraging and roosting habitat for the threatened Aleutian Canada goose (Branta canadensis leucopareia; Williams et al., 2008).

Much of the Refuge was previously leveled and cultivated for irrigated agriculture. A levee system separates the formerly cultivated portions of the Refuge from adjacent areas of brushy and riparian habitat. The land between the levees and the San Joaquin River is dominated by native blackberry (Rubus ursinus), willows (Salix spp.), mugwort (Artemisia douglasiana), and wild rose (Rosa californica). Prior to a wildfire in July 2004, the northeastern portion of the Refuge was occupied primarily by perennial pepperweed (Lepidium latifolium) with lesser contributions by other weed species.

Mean annual rainfall in Modesto is approximately $31.6 \mathrm{~cm}$. The mean temperature ranges from a low of $3.2^{\circ} \mathrm{C}$ (December) to a high of just over $34.5^{\circ} \mathrm{C}$ (July); extreme temperatures range from $-7.8{ }^{\circ} \mathrm{C}$ to $45^{\circ} \mathrm{C}$ (National Oceanic and Atmospheric Administration, 2006).

During the study period our translocation site experienced two major disturbances. In July 2004, an arson-caused wildfire (the Pelican wildfire) burned 588 ha of the Refuge, including 412 ha of the primary release locations and available habitat for brush rabbits. In March 2005, the riparian habitat at the Refuge was flooded due to larger than normal reservoir discharges on the Merced and Tuolumne rivers. During this event, two of three soft-release enclosures were inundated by $\geqslant 1 \mathrm{~m}$ of water; all soft-release enclosures were open at the time of the flood event. Flooding of Refuge riparian areas occurred again in May and June 2005 due to melting of an above-average snowpack in the Sierra Nevada.

\subsection{Reintroduction}

Captive-bred rabbits were reared in three 0.5 -ha outdoor enclosures established in habitat similar to that at release sites and 
approximately $64 \mathrm{~km}$ north of the Refuge (Williams et al., 2008). Between November 2001 and July 2005, 476 offspring were produced within the breeding enclosures. Of these, 325 individuals weighing $\geqslant 400 \mathrm{~g}$ (a single exception was one rabbit weighing $395 \mathrm{~g}$ ) were reintroduced to unoccupied habitat within their historic range over a period of 3 years from July 2002 to July 2005 (49, 231, and 45 individuals, respectively), all but one of which were fitted with radiocollars. Offspring captured in the propagation enclosures were examined under general anesthesia to ensure general health prior to translocation. Blood samples were collected and assessed for complete blood counts and analysis of serum chemistry; remaining serum was frozen for long-term storage (Black et al., 2009). Released animals weighed 395-1000 g; females were heavier than males (673 (SE 10) g, $n=163$, vs. 577 (SE 5) g, $n=161 ; t=8.37, p<0.0001)$. Rabbits were fitted with radiocollars (Advanced Telemetry Systems [ATS; Isanti, MN] model M1750, fitted on neoprene-impregnated cotton-duck belting collars) weighing approximately $13 \mathrm{~g}$ ( $2 \%$ of mean body mass; range $1.3-3.3 \%$ ), and with a battery life of 7 months to 1 year. Transmitters included an external whip antenna and contained mortality sensors that activated if animals remained motionless for $\geqslant 6 \mathrm{~h}$. The strap-type collar was secured by a nut and bolt. All handling procedures were approved by the University of California, Davis Animal Use and Care Administrative Advisory Committee, and met guidelines recommended by the American Society of Mammalogists (Gannon et al., 2007).

Rabbits were transported by vehicle for approximately $1 \mathrm{~h}$ on the day of capture and subsequently held individually in small, cat-sized pet carriers until release that afternoon or the following morning. Reintroduced individuals were soft-released in large (0.30-0.40 ha) enclosures of $2.54 \mathrm{~cm}$ poultry netting ca. $1.5 \mathrm{~m}$ tall. Enclosures were characterized by brushy habitat consisting of willow, California blackberry, mugwort, and wild rose. Rabbits were confined in the soft-release enclosures for 2-20 days (mean $=5$ days) to become familiar with places for shelter and retreat from predators. During the first year, the mean duration of confinement was 9.3 days; this was reduced to 4.6 and 5.6 days during years 2 and 3 , respectively. Multiple locations in the enclosures were opened to allow the rabbits to leave at will; openings were approximately 6-7 m wide. Of the 324 radiocollared animals, 1 individual sustained injuries while in captivity that may have compromised its physical condition; this animal was omitted from all analyses; this left a total of 323 radiocollared animals for demographic analyses.

Rabbits were captured for transmitter replacement prior to battery failure. Individuals were located with hand-held antennas (Telonics; Mesa, AZ) and portable receivers (Communications Specialists model R1000; Orange, CA). We set Tomahawk ${ }^{\mathrm{TM}}$ doubledoor, wire-mesh live-traps (Model 203; $61 \mathrm{~cm}$ long by $15.2 \mathrm{~cm}$ high and wide) at these locations, and baited them with a mix of fresh apples, rolled oats, and molasses. Captured rabbits were anesthetized for collar replacement and released at the site of capture within the same day.

Rabbits were monitored by radiotelemetry and direct observation to ensure that they remained alive during confinement. Staffing limitations disallowed daily monitoring during pre-release confinement after March 2004 but we monitored animals frequently after the enclosures were opened. Rabbits in the first two cohorts were monitored daily for a 5-day period after enclosures were opened, but in subsequent translocations we monitored rabbits $\geqslant$ twice per week over a period of 3 years (July 2002-July 2005). In general, we continued to monitor for missing individuals for approximately 2 months past the potential battery failure date.

When mortality signals were detected we collected the carcasses and transferred available remains to veterinarians for necropsy. When remains were unavailable, we estimated cause of death from available sign (e.g., presence of tooth marks or blood on the collar) or other environmental cues (e.g., existence of predator trails, scats, dens, or other signs). Mortalities were assigned to six categories (drowning, fire, illness, trap injury, predation, and unknown cause) and when possible, to specific causes (e.g., predation by avian, mammalian, or unknown predator).

\subsection{Survival analyses}

Of the 283 mortalities, 149 (53\%) occurred within 12 weeks of reintroduction (Fig. 2) and survival stabilized after this point. The elevated mortality immediately following translocation likely was related to the translocation itself, and would obscure assessment of longer-term survival of established animals. To account for this dichotomy, we pursued survival analyses in two phases. We examined survival during the first 12 weeks post-release in

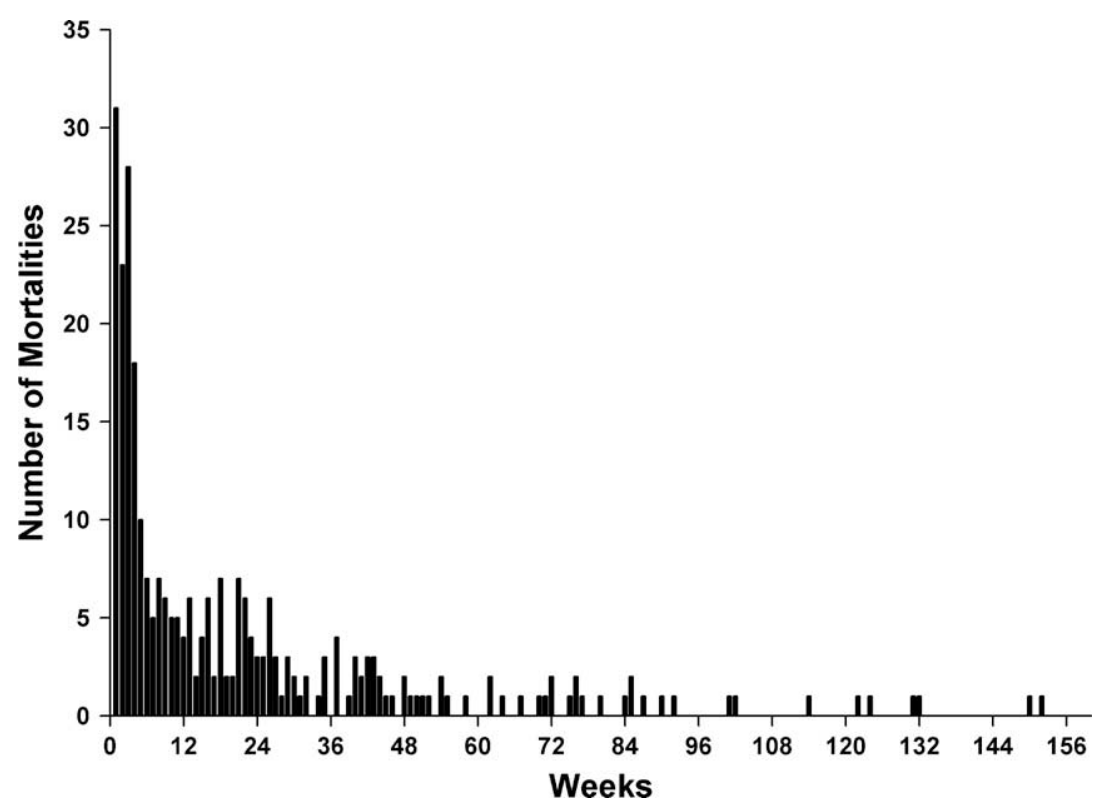

Fig. 2. Number of deaths occurring in each weekly (7-day) time period ( $n=283$ ). 
relation to specific parameters of interest to identify an interval during which rabbits were most susceptible to post-release mortality. We then focused on those individuals that lived through this "acclimation period," and evaluated temporal variation in survival (i.e., among years, seasons, and months) and the effects of catastrophic events including wildfire and flooding.

\subsubsection{Post-release survival}

We initiated our survival analyses by assessing the period over which immediate post-translocation mortality was greatest. Our logic was that animals that survived this initial period had acclimated to their new surroundings, and subsequent analyses (below) would more accurately assess survival of successfully translocated rabbits. We estimated the time period during which post-release mortality was an important influence using a nest survival model in program MARK (White and Burnham, 1999; Dinsmore et al., 2002; Rotella et al., 2004). Nest survival models do not require the exact mortality date for individuals and can be used for datasets where all radiocollared animals are not monitored simultaneously. We used the logit link function to estimate weekly survival of rabbits during the first 12 weeks post-release (White and Burnham, 1999; Dinsmore et al., 2002). We prepared detailed encounter histories for all rabbits, beginning with the week of release (defined as week 1 for all histories). For those not surviving the first 12-week period, we recorded the last week in which the animal was known to be alive and the last week in which we attempted to locate the animal or in which it was documented to be dead. For animals that survived the first 12-week period, the end date of the analysis was fixed (e.g., week 12). We excluded 25 rabbits that died in the first week post-release and 3 rabbits that died due to study-related accidents during the 12 -week period of analysis. Thus, nest survival models were run with data on 295 rabbits. We evaluated variation in survival as a function of sex, body mass at release, length of time in the soft-release enclosure (days in release pen $=\mathrm{DRP}$ ), reproductive condition (reproductive, e.g., scrotal, pregnant, lactating or in estrus; vs. non-reproductive), and release cohort size (the number of individuals in a translocation group).

\subsubsection{Post-acclimation survival}

To control for release mortality, we excluded from further analyses all individuals that post-release survival analysis indicated were most susceptible to post-translocation mortality. For the remaining 219 rabbits we applied a known-fate model (White and Burnham, 1999) to evaluate temporal variation in survival, including variation as a function of calendar month and season (summer, May 1-July 31; fall, August 1-October 31; winter, November 1-January 31; spring, February 1-April 30). We also modeled variation in survival due to two catastrophic events (the Pelican wildfire of July 2004 and catastrophic flooding in March 2005) by designating the specific months in which they occurred in program MARK. Additionally, we modeled variation in survival due to periods of high (November-May) vs. low (June-October) precipitation. In California, months with higher precipitation correspond with the peak breeding season for riparian brush rabbits (Mossman, 1955). In candidate models, we combined years 2 and 3 reflecting two key differences from the first year; DRP was almost twice as long in year 1 than in subsequent years, and brush rabbits were absent from the Refuge in the first year of our study whereas a resident population existed in subsequent years. We coded encounter histories by month for the 3-year period; thus, encounter histories spanned 36 intervals. To evaluate variation in survival as a function of specific release techniques, we included individual covariates in encounter histories. These covariates included body mass at release, release cohort size (the number of individuals in a translocation group), length of time in the soft-release enclosure
(DRP), and reproductive status at the time of release (reproductive vs. non-reproductive). We did not include sex as a covariate in this analysis because preliminary analysis based on the entire data using known-fate models indicated that both sexes experienced similar monthly survival rates $\left(\Phi_{\text {females }}=0.700, \mathrm{SE}=0.020\right.$; $\Phi_{\text {males }}=0.702, \mathrm{SE}=0.020$ ).

For both survival analyses, we developed an a priori set of candidate models and only evaluated models with an additive relationship between selected parameters that were biologically meaningful and interpretable (Burnham and Anderson, 2002). This included nine models for estimating post-release survival, and 14 models for evaluating temporal variation in survival and variation associated with catastrophic events. We applied Akaike's Information Criterion corrected for small sample sizes (AICc) to select among competing survival models, and the model with the lowest AICc was considered the best supported model given the data (Anderson et al., 2000; Burnham and Anderson, 2002). Under this approach, differences among models are represented by $\triangle \mathrm{AICC}$ (the gain in AICc over the model with the lowest value of AICc). Models with $\triangle \mathrm{AICc} \leqslant 2$ are considered to be better supported than other available candidate models, whereas those with $\triangle \mathrm{AICc}=2-4$ are poor, given the available data (Burnham and Anderson, 2002). Models with $\triangle \mathrm{AICC}>4$ are considered very poor and therefore noninformative. Akaike weights $\left(w_{i}\right)$ quantify the weight of evidence for model $i$ given that one of the models tested is the best model for the data. The relative importance (RI) of independent variables may be determined as the sum of $w_{i}$ across all models including that variable (Burnham and Anderson, 2002). Finally, evidence ratios ( $w_{i} / w_{j}$, where $j$ is the best estimated model) range from 0 to 1 , and provide insight into the relative evidence in favor of a given model; higher values indicate greater evidence for a given model.

\section{Results}

We located animals 2.5 (SE 0.17), 3.7 (SE 0.17), and 3.1 (SE 0.12) days/week in years 1-3 of the study, respectively. Of 323 animals used in demographic analyses, we recovered transmitters from $283(87.6 \%)$ individuals that were confirmed mortalities. We removed radiocollars from 8 additional individuals 229 (SE 20) days after reintroduction because of monitoring constraints. Additionally, we lost the radio-signals from 32 individuals 271 (SE 27) days after reintroduction, despite extensive searches throughout the area.

Cause of mortality (Fig. 3) was unknown for the majority of deaths (62.9\%), reflecting either limited or complete absence of remains other than the radiocollar. Four deaths were caused by disease; necrotizing typhlitis was observed twice, and dental malocclusion and encephalomalacia once each (Williams et al., 2008). Predation (including presumptive predation) was the greatest known cause of death in translocated rabbits (24.5\%).

Native-born rabbits in our study appeared to exhibit elevated survival in comparison to reintroduced rabbits (327 (SE 50) days, $n=22$ vs. 164 (SE 11 ) days, $n=323 ; t=-3.90, p<0.0001$ ), however, small sample sizes prohibited us from further integrating this into modeling of survival.

\subsection{Post-release survival}

The best approximating model of weekly survival immediately after release included variation associated with the first 4 weeks post-release as well as length of time in the soft-release enclosure (DRP; Table 1). Under this model, weekly survival probabilities were substantially lower in the first 4 weeks $\left(\Phi_{\text {weeks } 1-4}=0.917\right.$, $\Phi_{\text {weeks } 5-12}=0.971$, corresponding with monthly survival of 0.707 


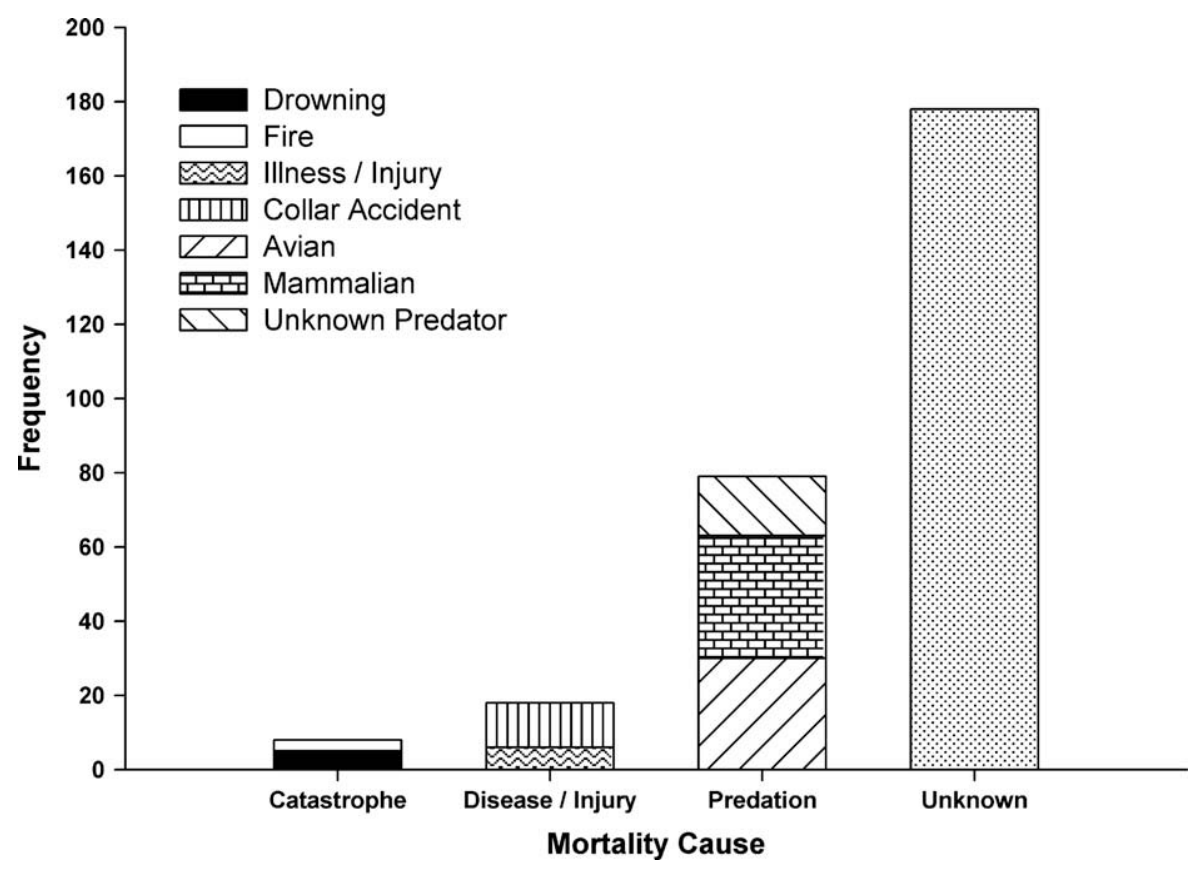

Fig. 3. Sources of brush rabbit mortality at the San Joaquin River NWR between July 2002 and July 2005 ( $n=283$ ).

Table 1

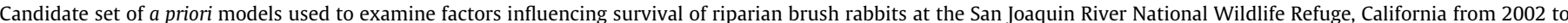

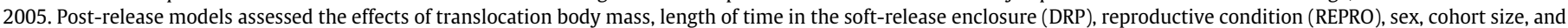

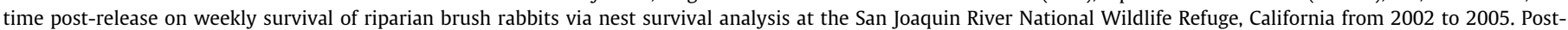

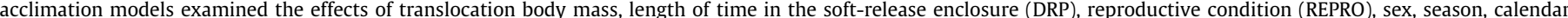

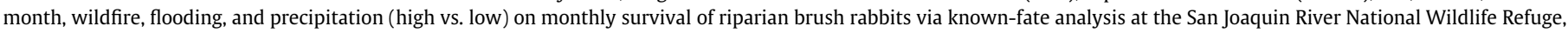
California from 2002 to 2005 . Note that the former models assessed weekly survival, whereas the latter assessed monthly survival.

\begin{tabular}{|c|c|c|c|c|c|c|}
\hline Model & $\mathrm{AICc}$ & $\triangle \mathrm{AICc}$ & $w_{i}$ & Evidence ratio $\left(w_{i} / w_{1}\right)$ & Num. par. & Deviance \\
\hline \multicolumn{7}{|l|}{ Post-release survival } \\
\hline$\Phi\left\{\right.$ Week $_{(1-4)}+$ DRP $\}$ & 891.39 & 0 & 0.30 & 1 & 3 & 885.38 \\
\hline$\Phi\left\{\right.$ Week $_{(1-4)}+$ DRP + mass $\}$ & 891.73 & 0.34 & 0.27 & 0.84 & 4 & 883.71 \\
\hline$\Phi\left\{\right.$ Week $\left._{(1-4)}\right\}$ & 893.52 & 2.13 & 0.10 & 0.35 & 2 & 889.51 \\
\hline$\Phi\left\{\right.$ Week $_{(1-4)}+$ mass $\}$ & 893.63 & 2.24 & 0.10 & 0.33 & 3 & 887.62 \\
\hline$\Phi\left\{\right.$ Week $_{(1-4)}+$ sex $\}$ & 893.74 & 2.35 & 0.09 & 0.31 & 3 & 887.73 \\
\hline$\Phi\left\{\right.$ Week $\left._{(1-3}\right\}$ & 894.63 & 3.24 & 0.06 & 0.20 & 2 & 890.62 \\
\hline$\Phi\left\{\right.$ Week $_{(1-4)}+$ cohort $\}$ & 895.33 & 3.94 & 0.04 & 0.14 & 3 & 889.32 \\
\hline$\Phi\left\{\right.$ Week $_{(1-4)}+$ repro $\}$ & 895.52 & 4.12 & 0.04 & 0.13 & 3 & 889.51 \\
\hline$\Phi\{t\}$ & 901.70 & 10.31 & 0 & 0.01 & 11 & 879.59 \\
\hline$\Phi\{\cdot\}$ & 924.15 & 32.75 & 0 & 0 & 1 & 922.14 \\
\hline \multicolumn{7}{|l|}{ Post-acclimation survival } \\
\hline$\Phi\{$ Year 1 vs. years 2 and $3+$ Flood + DRP $\}$ & 892.02 & 0 & 0.31 & 1.00 & 4 & 884.00 \\
\hline$\Phi\{$ Year 1 vs. years 2 and $3+$ Flood $\}$ & 892.45 & 0.43 & 0.25 & 0.81 & 3 & 886.44 \\
\hline$\Phi\{$ Year 1 vs. years 2 and $3+$ Flood + mass $\}$ & 892.47 & 0.44 & 0.25 & 0.80 & 4 & 884.44 \\
\hline$\Phi\{$ Year 1 vs. years 2 and $3+$ flood + repro $\}$ & 894.25 & 2.22 & 0.10 & 0.33 & 4 & 886.22 \\
\hline$\Phi\{$ Year 1 vs. years 2 and $3+$ flood + sex $\}$ & 894.46 & 2.43 & 0.09 & 0.30 & 4 & 886.43 \\
\hline$\Phi\{$ Month + flood $\}$ & 902.03 & 10.00 & 0 & 0.01 & 13 & 875.77 \\
\hline$\Phi\{$ Year 1 vs. years 2 and 3$\}$ & 902.03 & 10.01 & 0 & 0 & 2 & 898.02 \\
\hline$\Phi\{$ Flood vs. nonflood $\}$ & 905.88 & 13.85 & 0 & 0 & 2 & 901.87 \\
\hline$\Phi\{t\}$ & 908.85 & 16.83 & 0 & 0 & 31 & 845.45 \\
\hline$\Phi\{$ Month $\}$ & 910.95 & 18.92 & 0 & 0 & 12 & 886.73 \\
\hline$\Phi\{$ Season + flood $\}$ & 911.31 & 19.29 & 0 & 0 & 5 & 901.27 \\
\hline$\Phi\{$ Pre- vs. post-fire $\}$ & 915.72 & 23.70 & 0 & 0 & 2 & 911.72 \\
\hline$\Phi\{\cdot\}$ & 917.69 & 25.67 & 0 & 0 & 1 & 915.69 \\
\hline$\Phi\{$ Rainy vs. dry $\}$ & 919.29 & 27.27 & 0 & 0 & 2 & 915.28 \\
\hline$\Phi\{$ Season $\}$ & 920.87 & 28.84 & 0 & 0 & 4 & 912.84 \\
\hline
\end{tabular}

and 0.889, respectively; Table 2). However, the second model $(\triangle \mathrm{AICC}=0.34)$ included these variables as well as mass. Modelaveraged results indicated that both DRP and mass influenced survival (Table 3), and suggested that the effect of DRP was greater for smaller animals (Fig. 4). Furthermore, the relative importance values for the variables in the top models $(\triangle \mathrm{AICC}>2$; $\mathrm{RI}=0.56$ and
0.36 for DRP and mass, respectively; Table 3) identified DRP as a primary factor in determining rabbit survival rates, followed by mass. Because confidence intervals for these variables overlap zero, the effects of these factors on survival rates should be interpreted with caution. A model incorporating only weeks 1-4, however, yielded a poor fit to our data $(\triangle \mathrm{AICc}=2.13$; Table 1$)$. All time peri- 
Table 2

Survival estimates, SE, and 95\% confidence intervals for the top model sets of the postrelease and post-acclimation survival analyses. Note that parameter estimates are not available for continuous covariates (e.g., DRP, Mass).

\begin{tabular}{|c|c|c|c|}
\hline Model/parameter & $\Phi$ & SE & LCI-UCI \\
\hline \multicolumn{4}{|c|}{$\begin{array}{l}\text { Post-release survival } \\
\Phi\left\{\text { Week }_{(1-4)}+\text { DRP }\right\}\end{array}$} \\
\hline Week $_{1-4}$ & 0.917 & 0.009 & $0.899-0.933$ \\
\hline Week $_{5-12}$ & 0.971 & 0.005 & $0.961-0.979$ \\
\hline \multicolumn{4}{|c|}{$\Phi\left\{\right.$ Week $_{(1-4)}+\mathrm{DRP}+$ mass $\}$} \\
\hline Week $_{1-4}$ & 0.918 & 0.009 & $0.899-0.933$ \\
\hline Week $_{5-12}$ & 0.971 & 0.005 & $0.961-0.979$ \\
\hline \multicolumn{4}{|c|}{$\begin{array}{l}\text { Post-acclimation survival } \\
\Phi\{\text { Year } 1 \text { vs. years } 2 \text { and } 3+\text { flood }+ \text { DRP }\}\end{array}$} \\
\hline Year 1 & 0.949 & 0.015 & $0.909-0.997$ \\
\hline Years 2 and 3 & 0.897 & 0.009 & $0.877-0.914$ \\
\hline Flood & 0.634 & 0.098 & $0.430-0.798$ \\
\hline \multicolumn{4}{|c|}{$\Phi\{$ Year 1 vs. years 2 and $3+$ flood $\}$} \\
\hline Year 1 & 0.960 & 0.011 & $0.932-0.976$ \\
\hline Years 2 and 3 & 0.894 & 0.009 & $0.874-0.911$ \\
\hline Flood & 0.625 & 0.099 & $0.422-0.792$ \\
\hline \multicolumn{4}{|c|}{$\Phi\{$ Year 1 vs. years 2 and $3+$ flood + mass $\}$} \\
\hline Year 1 & 0.961 & 0.011 & $0.934-0.977$ \\
\hline Years 2 and 3 & 0.893 & 0.009 & $0.873-0.910$ \\
\hline Flood & 0.613 & 0.101 & $0.408-0.784$ \\
\hline
\end{tabular}

Table 3

Model-averaged parameter estimates, SE, 95\% confidence intervals and relative importance values for the variables contained in the top model sets for each analysis, post-release survival and post-acclimation survival.

\begin{tabular}{lrlll}
\hline Parameter & Beta & SE & LCI-UCI & RI \\
\hline Post-release survival & & & & \\
Week(1-4) & 1.1158 & 0.4535 & $0.2269-2.0046$ & 0.94 \\
DRP & 0.0345 & 0.1061 & -0.1735 to 0.2426 & 0.56 \\
Mass & 0.0004 & 0.0109 & -0.0210 to 0.0218 & 0.36 \\
Post-acclimation survival & & & & \\
Year 1 vs. years 2 and 3 & -0.7712 & 0.4939 & -1.7392 to 0.1968 & 1.0 \\
Flood & -1.3188 & 0.5894 & -2.4741 to -0.1635 & 1.0 \\
DRP & 0.0139 & 0.0543 & -0.0926 to 0.1204 & 0.31 \\
Mass & 0.0003 & 0.0069 & -0.0133 to 0.0138 & 0.25 \\
\hline
\end{tabular}

ods not shown in Table 1 (e.g., weeks $1-2,1-5$, etc.) were very poorly supported (e.g., $\triangle \mathrm{AICc}>6$ ). There was no support for a model with constant weekly survival $\Phi\{\cdot\}(\Delta$ AICC $>32)$.

\subsection{Post-acclimation survival}

For animals that survived the 4-week acclimation period, three models were well supported $(\triangle \mathrm{AICc}<2$; Table 1$)$ and incorporated important information for understanding survival in this system $\left(w_{i}=0.81\right)$. These models all included the effects of year $1 \mathrm{vs}$. years 2 and 3, and the influence of the March 2005 flooding event. The slight overlap in confidence intervals between year 1 and years 2 and 3 argues for some caution in interpreting the importance of this effect. Separate models for the independent role of these factors provided a poor fit to the data (both $\triangle \mathrm{AICC}=10$ ), indicating that these parameters had strong additive effects on rabbit survival; indeed, the relative importance of each of these was 1.0 and was $>3$ times higher than for any other variable. The most parsimonious model also included length of time in the soft-release enclosure (DRP), although the relative importance of this variable was much lower $(\mathrm{RI}=0.31$, Table 3 ). Monthly survival probabilities were high during the first year, but declined in years 2 and 3 (Table 2); survival dropped further during the March 2005 flood (Table 2). Model-averaged results (Table 3 ) emphasized the dominant influence of the flooding event relative to years, DRP, or mass. However, as with post-release survival, the confidence intervals for these variables overlap zero, so should be interpreted with caution.

There was no support for variation in survival due to the Pelican wildfire $(\triangle \mathrm{AICC}>23)$ or as a function of month or season of release ( $\triangle \mathrm{AICC}>18$ and 28 , respectively). Additionally, there was no support for variation due to periods of high or low precipitation $(\triangle \mathrm{AICC}>27)$.

\section{Discussion}

Species reintroductions commonly face high post-release mortality, whereas animals that survive the initial "acclimation" period may be impacted by other mortality factors than those affecting newly released animals. We segregated our analyses into two peri-

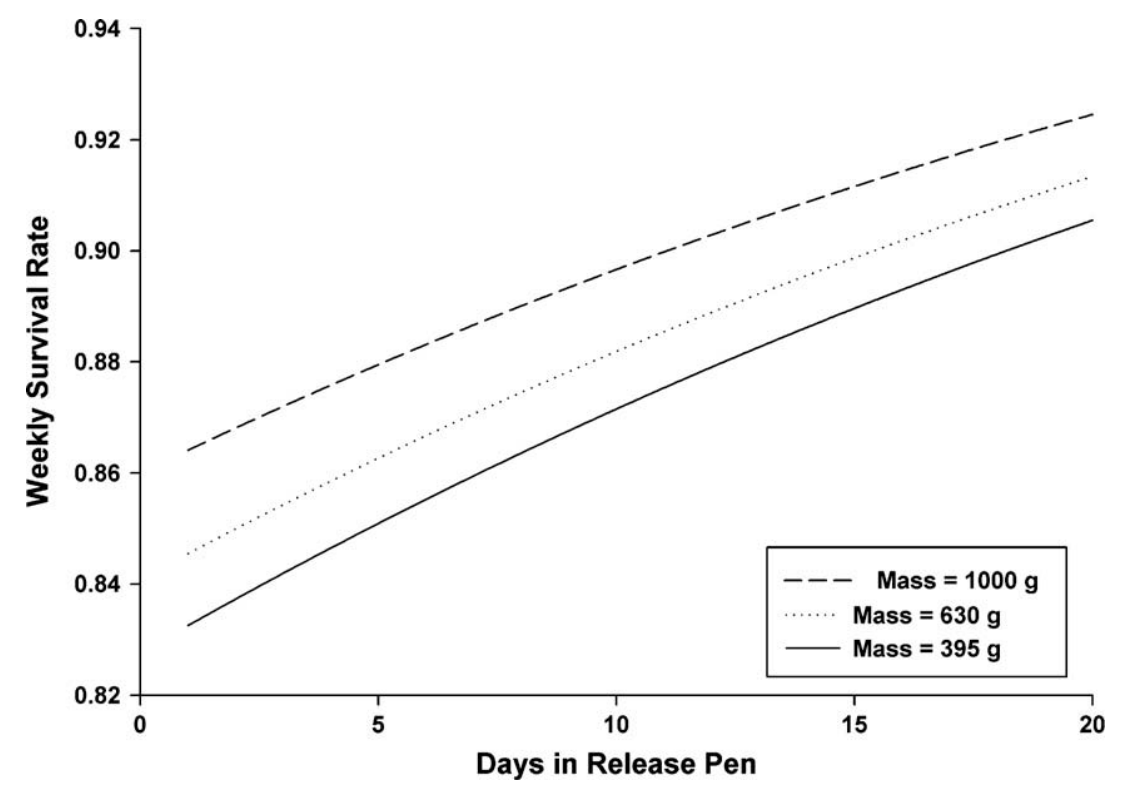

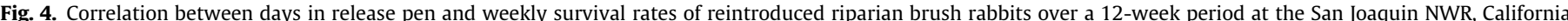

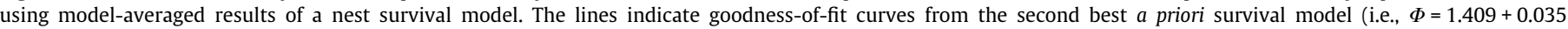
$( \pm 0.106) *(\mathrm{DRP})+0.0004( \pm 0.011) *$ mass $)$. Mass kept constant at minimum $(395 \mathrm{~g})$, mean $(630 \mathrm{~g})$ and maximum $(1000 \mathrm{~g})$ of the observed masses. 
ods representing immediate responses to release, followed by longer-term survival by animals that survived the initial acclimation.

In our study the "post-release" period was best defined as comprising the first 4 weeks after release pens were opened. Survival was lowest during this period ( $\mathrm{RI}_{\text {weeks }} 1-4=0.94$; Table 3 ) and was best explained by the length of time animals were retained in release pens $\left(\mathrm{RI}_{\mathrm{DRP}}=0.56\right)$. Body size was also important $(R I=0.36)$ but was substantially less influential than DRP. No other variables were important in explaining survival during this period. High levels of post-release mortality have also been documented in European rabbits (Oryctolagus cuniculus; Calvete et al., 1997; Letty, 1998; Letty et al., 2002) and swamp rabbits (Sylvilagus aquaticus; Watland et al., 2007).

High post-release mortality could indicate that larger groups of individuals may be required for population establishment and persistence (Armstrong and Seddon, 2008). Releasing larger groups might mitigate any increased mortality associated with acclimation and might ensure that some individuals remain in sufficient proximity for reproduction. This, in turn, may reduce potential differences between the effective initial population size and the size of the release group (Armstrong and Seddon, 2008).

For those rabbits that survived the acclimation period, subsequent survival was greater in year 1 than in years 2 and 3 (see also Williams et al., 2008) and was strongly impacted by the flooding event in March 2005 (Tables 2 and 3). In spite of the fact that this analysis filtered out all rabbits that did not survive the first 4 weeks post-release, DRP remained an important factor explaining post-acclimation survival ( $R I=0.31$; Table 3$)$. Not surprisingly, mass influenced survival as well $(\mathrm{RI}=0.25)$.

An acclimation period is beneficial for some species (Davis, 1983; Moore and Smith, 1991; Bright and Morris, 1994; Carbyn et al., 1994; Biggins et al., 1999), whereas it fails to improve survival probabilities for others (Fiechter et al., 1988; Castro et al., 1994; Thompson et al., 2001; Hardman and Moro, 2006). Few studies have examined the effect of acclimation on rabbits. Among acclimated European rabbits, females demonstrated higher postrelease survival than males, but individuals captured, held, and released into a familiar environment exhibited lower mortality than those translocated to a new location (Letty et al., 2003), indicating that environmental novelty could be responsible for high levels of release mortality. Similarly, translocated snowshoe (Lepus americanus) and mountain hares (Lepus timidus) exhibited increased mortality and movements early after release relative to resident individuals (Lemnell and Lindlöf, 1982; Sievert and Keith, 1985). It is worth noting that native-born rabbits in our study appeared to exhibit elevated survival relative to reintroduced rabbits, suggesting that environmental novelty might decrease survival rates in riparian brush rabbits.

The greater survival during the first year of our study is intriguing. Although we cannot categorically explain this, we pose three reasonable explanations. First, we reduced the acclimation period in the second and third years of this project (mean DRP reduced from 9.3 days in year 1 to 4.6 and 5.6 days, respectively), and given the importance of this parameter it seems likely that this is at least a partial explanation for this decline. Two other key factors are predation and habitat availability.

If brush rabbit populations are regulated by predation, the presence of rabbits in year 1 may have led to a positive functional response by predators, with increased predation in subsequent years. Unfortunately we were not able to collect data on predator abundances. However, although riparian brush rabbits are consumed by many species, their small size $(\sim 500-1000 \mathrm{~g})$ means that many carcasses likely were completely consumed before we could recover them, making our estimate of predation a conservative one. At any rate, predation is a primary cause of death in other lag- omorphs (Chapman and Litvaitis, 2003; Gibb et al., 1978; Moriarty et al., 2000; Henning et al., 2008), and was the greatest known cause of deaths in our translocated rabbits (Fig. 3), accounting for one fourth of mortality.

If rabbit populations are regulated by the distribution and quality of habitat, then partial saturation from initial releases may have restricted establishment in subsequent years. This seems somewhat unlikely since only 49 riparian brush rabbits were released in year 1; however, desert cottontails were present on the Refuge throughout the duration of the study, and may have co-opted high quality habitat. Disentangling the relative importance of each of these potential influences should be a priority in subsequent research. Barring such information, our results support earlier recommendations for large initial releases rather than numerous smaller releases over multiple years (Williams et al., 2008).

While flooding greatly impacted rabbit survival, we found little support for such an influence by the Pelican wildfire. Only one monitored brush rabbit showed direct evidence of fire-related trauma, and two desert cottontails captured during subsequent surveys exhibited fire-related injuries. Whereas the Pelican wildfire burned approximately 58\% (432 ha) of the Refuge, it bypassed approximately $66 \%$ of the highly suitable, dense riparian habitat along slough channels supporting the majority of radiocollared rabbits (Hamilton et al., in preparation). Thus, the limited impact on rabbit survival was a consequence of the spatial distribution of this fire, likely because of the differences in vegetation.

Not surprisingly, body mass correlated positively with survival both immediately after release and after the acclimation period. Body mass also is correlated with age in brush rabbits (Williams et al., 2008), so larger individuals likely were older and better able to evade predators. Increased body mass also might have conferred benefits to translocated individuals by allowing them to better cope with locating food and cover, and by providing body fat reserves to assist in disease resistance/recovery or in offsetting physiological costs associated with reproductive activities (Gaillard et al., 2000).

We found no support for temporal variation in rabbit survival, based either on calendar months or on rainy vs. dry seasons. These results are consistent with research on introduced European rabbits in Spain (Moreno et al., 2004), but contrast with data on eastern cottontails (Sylvilagus floridanus), which exhibited seasonal differences in survival rates (Bond et al., 2001). The moderate winter climate in central California may have diminished such seasonal differences in our study.

\subsection{Management implications}

Perhaps the most trenchant lesson from this program is that reintroduction programs must be treated within an adaptive management framework. In our study, survival decreased markedly during the second year of reintroduction, likely a consequence of competition for resources with established rabbits and reduced time in release pens. Implementing survival analyses earlier in the reintroduction program would have prompted retention of rabbits in release pens for longer periods during subsequent release years after year 2 . We recommend that ongoing survival analyses be implemented as soon as data are first available in reintroduction programs that involve more than one release of animals. Additionally, data analysis should proceed in concert with field activities to evaluate population responses and allow managers to adjust reintroduction techniques as conditions dictate. The other factor that emerged as critical for survival of riparian brush rabbits was the catastrophic flooding event. Given the riparian habitat preferences of riparian brush rabbits, flooding should be anticipated in future releases, and habitat corridors managed to allow animals to reach higher ground as temporary refuge. Lessons learned here can be 
integrated into ongoing efforts to protect this endangered species, and to ensuring that viable populations are resilient in the face of known and unanticipated extrinsic factors.

\section{Acknowledgements}

This work (trapping, handling, radiotelemetry, and reintroduction) was conducted under permits issued to DFW and PAK by the US Fish and Wildlife Service and the California Department of Fish and Game. Funding for this cooperative project has been provided by many agencies and programs, including: US Bureau of Reclamation (Conservation Program; Habitat Restoration Program; South Central California Area Office in Fresno), CALFED (Sacramento-San Joaquin Delta water quality program between the State of California and the US Federal Government), US Fish and Wildlife Service (San Luis National Wildlife Refuge Complex; Burned Area Emergency Response; Sacramento Fish and Wildlife Office; Pacific Southwest Region Office), and the California Department of Fish and Game. We thank members of the Riparian Mammals Technical Group for ongoing funding, discussion, advice, logistical and other support. We are grateful to the veterinarians of the UC Davis Wildlife Health Center and Veterinary Medical Teaching Hospital, particularly Kirsten Gilardi and Scott Larsen, for their care and expertise. We also thank River Islands, LLC, especially Susan Dell'Osso, for allowing us to capture riparian brush rabbits on their property to use as brood stock in the controlled propagation program. For their many hours of hard work and their dedication to this project, we thank the past and present members of the riparian brush rabbit team and the California State University, Stanislaus-Endangered Species Recovery Program, particularly Matthew Lloyd, Scott Phillips, and Elizabeth Williams. We are grateful for the insightful suggestions of two anonymous reviewers on earlier versions of this manuscript.

\section{References}

Alberts, A.C., 2007. Behavioral considerations of headstarting as a conservation strategy for endangered Caribbean rock iguanas. Applied Animal Behaviour Science 102, 380-391.

Anderson, D.R., Burnham, K.P., Thompson, W.L., 2000. Null hypothesis testing: problems, prevalence, and an alternative. Journal of Wildlife Management 64, 912-923.

Armstrong, D.P., Seddon, P.J., 2008. Directions in reintroduction biology. Trends in Ecology and Evolution 23, 20-25.

Biggins, D.E., Vargas, A., Godbey, J.L., Anderson, S.H., 1999. Influence of prerelease experience on reintroduced black-footed ferrets (Mustela nigripes). Biological Conservation 89, 121-129.

Black, D.M., Gilardi, K.V.K., Hamilton, L.P., Williams, E., Williams, D.F., Kelly, P.A., Gardner, I., 2009. Hematologic and clinical chemistry reference values for the endangered riparian brush rabbit (Sylvilagus bachmani riparius). Journal of Wildlife Diseases 45, 491-496.

Bond, B.T., Burger, L.W., Leopold, B.D., Godwin, K.D., 2001. Survival of cottontail rabbits (Sylvilagus floridanus) in Mississippi and an examination of latitudinal variation. American Midland Naturalist 145, 127-136.

Bright, P.W., Morris, P.A., 1994. Animal translocation for conservation-performance of dormice in relation to release methods, origin and season. Journal of Applied Ecology 31, 699-708.

Burnham, K.P., Anderson, D.R., 2002. Model Selection and Multimodel Inference: A Practical Information - Theoretic Approach, second ed. Springer-Verlag, New York.

Calvete, C., Villafuerte, R., Lucientes, J., Osacar, J.J., 1997. Effectiveness of traditional wild rabbit restocking in Spain. Journal of Zoology 241, 271-277.

Carbyn, L.N., Armbruster, H.J., Mamo, C., 1994. The swift fox reintroduction program in Canada from 1983 to 1992. In: Bowles, M.L., Whelan, C.J. (Eds.), Restoration of Endangered Species: Conceptual Issues, Planning and Implementation. Cambridge University Press, Cambridge, pp. 247-269.

Castro, I., Alley, J.C., Empson, R.A., Minot, E.O., 1994. Translocation of hihi or stitchbird (Notiomystis cincta) to Kapiti Island, New Zealand: transfer techniques and comparison of release strategies. In: Serena, M. (Ed.), Reintroduction Biology of Australian and New Zealand Fauna. Surrey Beatty and Sons, Australia, pp. 113-121.

CDFG (California Department of Fish and Game), 2008. State and federally listed endangered and threated animals of California. <http://www.dfg.ca.gov/ biogeodata/cnddb/pdfs/TEAnimals.pdf> (viewed 02.01.09).
Chapman, J.A., 1971. Orientation and homing of the brush rabbit (Sylvilagus bachmani). Journal of Mammalogy 52, 686-699.

Chapman, J.A., Litvaitis, J.A., 2003. Eastern cottontail. In: Feldhammer, G.A., Thompson, B.C., Chapman, J.A. (Eds.), Wild Mammals of North America: Biology, Management, and Conservation. Johns Hopkins University Press, Baltimore, pp. 101-125.

Davis, M.H., 1983. Post-release movements of introduced Marten. Journal of Wildlife Management 47, 59-66.

Dinsmore, S.J., White, G.C., Knopf, F.L., 2002. Advanced techniques for modeling avian nest survival. Ecology 83, 3476-3488.

Fiechter, A., Benmergui, M., Marchandeau, S., Scherrer, B., François, A., Labous, Y. 1988. Influence of the methods of release and rearing on the success of releasing operation of leverets Lepus europaeus. Gibier Faune Sauvage 5, 1-14.

Fischer, J., Lindenmayer, D.B., 2000. An assessment of the published results of animal relocations. Biological Conservation 96, 1-11.

Gaillard, J.M., Festa-Bianchet, M., Delorme, D., Jorgenson, J., 2000. Body mass and individual fitness in female ungulates: bigger is not always better. Proceedings of the Royal Society of London Series B Biological Sciences 267, 471-477.

Gannon, W.L., Sikes, R.S., The Animal Care and Use Committee of the American Society of Mammalogists, 2007. Guidelines of the American Society of Mammalogists for the use of wild mammals in research. Journal of Mammalogy 88, 809-823.

Gibb, J.A., Ward, C.P., Ward, G.D., 1978. Natural Control of a Population of Rabbits, Oryctolagus cuniculus (L.), for Ten Years in the Kourarau Enclosure. New Zealand Department of Scientific and Industrial Research Bulletin No. 223, 89pp.

Griffith, B., Scott, J.M., Carpenter, J.W., Reed, C., 1989. Translocation as a species conservation tool: status and strategy. Science 245, 477-480.

Hardman, B., Moro, D., 2006. Optimising reintroduction success by delayed dispersal: is the release protocol important for hare-wallabies? Biological Conservation 128, 403-411.

Henning, J., Pfeiffer, D.U., Davies, P.R., Stevenson, M.A., Meers, J., 2008. Mortality patterns over 3 years in a sparse population of wild rabbits (Oryctolagus cuniculus) in New Zealand, with an emphasis on rabbit haemorrhagic disease (RHD). European Journal of Wildlife Research 54, 619-626.

Kleiman, D.G., 1989. Reintroduction of captive mammals for conservation Bioscience 39, 152-161.

Larsen, C.J., 1993. Status Review of the Riparian Brush Rabbit (Sylvilagus bachmani riparius) in California. California Dept. Fish and Game, Sacramento, Nongame Bird and Mammal Sec. Rep. 93-12, 39pp.

Lemnell, P.A., Lindlöf, L., 1982. Experimental release of captive-reared mountain hares. Swedish Wildlife Research (Viltrevy) 12, 115-128.

Letty, J., 1998. Le coût biologique de la réintroduction: approche expérimentale chez le Lapin de garenne (Oryctolagus cuniculus L.). Ph.D. Thesis, Université Pierre et Marie Curie, Paris.

Letty, J., Marchandeau, S., Reitz, F., Clobert, J., Sarrazin, F., 2002. Survival and movements of translocated wild rabbits (Oryctolagus cuniculus). Game and Wildlife Science 19, 1-23.

Letty, J., Aubineau, J., Marchandeau, S., Clobert, J., 2003. Effect of translocation on survival in wild rabbit (Oryctolagus cuniculus). Mammalian Biology 68, 250255.

McLean, I.G., 1997. Conservation and the ontogeny of behavior. In: Clemmons, J.R., Buchholz, R. (Eds.), Behavioral Approaches to Conservation in the Wild Cambridge University Press, Cambridge, pp. 132-156.

Moore, D.E., Smith, R. 1991. The red wolf as a model for carnivore re-introductions. In: Gipps, J.H.W. (Ed.), Beyond Captive Breeding: Reintroducing Endangered Mammals to the Wild. Clarendon Press, Oxford, pp. 263-278.

Moreno, S., Villafuerte, R., Cabezas, S., Lombardi, L., 2004. Wild rabbit restocking for predator conservation in Spain. Biological Conservation 118, 183-193.

Moriarty, A., Saunders, G., Richardson, B.J., 2000. Mortality factors acting on adult rabbits in central-western New South Wales. Wildlife Research 27, 613619.

Mossman, A.S., 1955. Reproduction of the brush rabbit in California. Journal of Wildlife Management 19, 177-184.

Oceanic and Atmospheric Administration, 2006. Local Climatological Data Stockton, California. National Climatological Data Center, Ashville, North Carolina.

Orr, R.T., 1940. The Rabbits of California. Occasional Papers of the California Academy of Sciences, No. 14. California Academy of Sciences, San Francisco, CA 227pp.

Rotella, J.J., Dinsmore, S.J., Schaffer, T.L., 2004. Modeling nest-survival data: a comparison of recently developed methods that can be implemented in MARK and SAS. Animal Biodiversity and Conservation 27, 187-205.

Sarrazin, F., Barbault, R., 1996. Reintroduction: challenges and lessons for a basic ecology. Trends in Ecology and Evolution 11, 474-478.

Seddon, P.J., Armstrong, D.P., Maloney, R.F., 2007. Developing the science of reintroduction biology. Conservation Biology 21, 303-312.

Shier, D.M., 2006. Effect of family support on the success of translocated blacktailed prairie dogs. Conservation Biology 20, 1780-1790.

Sievert, P.R., Keith, L.B., 1985. Survival of snowshoe hares at a geographic range boundary. Journal of Wildlife Management 49, 854-866.

Snyder, N.F., Derrickson, S.R., Beissinger, S.R., Wiley, J.W., Smith, T.B., Toone, W.D. 1996. Limitations of captive breeding in endangered species recovery. Conservation Biology 10, 338-348.

Thompson, J.R., Bleich, V.C., Torres, S.G., Mulcahy, G.P., 2001. Translocation techniques for mountain sheep: does the method matter? The Southwestern Naturalist 46, 87-93. 
USFWS (US Fish and Wildlife Service), 1998. Recovery Plan for Upland Species of the San Joaquin Valley, California. Region 1, Portland, Oregon, 319pp. <http:// ecos.fws.gov/docs/recovery_plans/1998/980930a.pdf>.

USFWS (US Fish and Wildlife Service), 2000. Endangered and threatened wildlife and plants; final rule to list the riparian brush rabbit and the riparian, or San Joaquin Valley, Woodrat as Endangered. Federal Register 65, 88818890 .

van Heezik, Y., Seddon, P.J., Maloney, R.F., 1999. Helping reintroduced houbara bustards avoid predation: effective anti-predator training and the predictive value of pre-release behaviour. Animal Conservation 2, 155-163.

Warner, R.E., 1984. Structural, floristic, and condition inventory of Central Valley riparian systems. In: Warner, R.E., Hendrix, K.M. (Eds.), California Riparian Systems Ecology, Conservation, and Productive Management. University of California Press, Berkeley, pp. 356-374.

Watland, A.M., Schauber, E.M., Woolf, A., 2007. Translocation of swamp rabbits in southern Illinois. Southeastern Naturalist 6, 259-270.

White, G.C., Burnham, K.P., 1999. Program MARK: survival estimation from populations of marked animals. Bird Study 46 (Suppl.), 120-138.

Williams, D.F., 1988. Ecology and Management of the Riparian Brush Rabbit in Caswell Memorial State Park. California Department of Parks and Recreation,
Final Report, Interagency Agreement, 4-305-6108, Lodi, CA, 38pp. <http:// esrp.csustan.edu/resources/publications/pdf/williams_1988_caswell_rbr.pdf $>$. Williams, D.F., Basey, G.E., 1986. Population Status of the Riparian Brush Rabbit, Sylvilagus bachmani riparius. California Department of Fish and Game, Sacramento, Wildlife Management Division, Nongame Bird and Mammal Section, Contract Final Report. 1986. <http://esrp.csustan.edu/resources/ publications/pdf/williams_basey_popstatrbr1986r.pdf $>$.

Williams, D.F., Kelly, P.A., Hamilton, L.P., 2002. Controlled Propagation and Reintroduction Plan for the Riparian Brush Rabbit. Endangered Species Recovery Program, California State University, Turlock 75pp. <http:// www.esrp.org/csus/publications/pdf/rbr_prop_plan_final-official.pdf>.

Williams, D.F., Kelly, P.A., Hamilton, L.P. Lloyd, M.R., Williams, E. A, Youngblom, J.J. 2008. Recovering the endangered riparian brush rabbit (Sylvilagus bachmani riparius): reproduction and growth in confinement and survival after translocation. In: Alves, P.C., Ferrand, N., Hacklander, K. (Eds.), Lagomorph Biology: Evolution, Ecology, and Conservation. Springer-Verlag, Berlin Heidelberg, pp. 349-361.

Wolf, C.M., Griffith, B., Reed, C., Temple, S.A., 1996. Avian and mammalian translocations: update and reanalysis of 1987 survey data. Conservation Biology 10, 1142-1154. 